\title{
Türkiye'de Kamu İç Borçlanmasının Gelir Eşitsizliği Üzerindeki Asimetrik Etkisi
}

\section{Önder ÇALCALI ${ }^{1}$}

\begin{tabular}{ccc}
\hline Geliş Tarihi/ Received & Kabul Tarihi/ Accepted & Yayın Tarihi/ Published \\
$17 / 04 / 2020$ & $27 / 11 / 2020$ & $15 / 01 / 2021$ \\
\hline Citation/Atıf: Çalcall, Ö., (2021), Türkiye'de Kamu Iç Borçlanmasinın Gelir Essitsizliği \\
Üzerindeki Asimetrik Etkisi, Atatürk Üniversitesi İktisadi ve İdari Bilimler Dergisi, 35(1): \\
Sayfa: $59-81$, https://doi.org/10.16951/atauniiibd.722351
\end{tabular}

Öz: Bu çalışmada Türkiye'de kamu iç borçlanmasının gelir eşitsizliği üzerindeki asimetrik etkileri araştırılmıştır. Bu amaçla 1980-2015 dönemi yıllık verileri kullanılarak seriler arasındaki asimetrik etkilerin belirlenmesini sağlayan NARDL (Asimetrik Gecikmesi Dağıtılmış Otoregresif) modeli tercih edilmiştir. Ampirik analiz kapsamında bağımlı değişken olarak gelir eşitsizliği kullanılmış olup, temel açıklayıcı değişken kapsamında kamu iç borçlanması ve kontrol değişkenleri olarak ekonomik büyüme, doğrudan yabancı yatırımlar ve ticari dışa açıklık değişkenleri kullanılmıştır. Elde edilen sonuçlar gelir eşitsizliği ve kamu iç borçlanması arasında uzun dönemde asimetrik, kısa dönemde ise simetrik bir ilişki olduğunu göstermiştir. Uzun dönemde kamu iç borçlanmasında meydana gelen negatif bir şokun gelir eşitsizliğini istatistiki olarak anlamlı ve negatif yönde etkilediği belirlenmiştir. Kısa dönemde de benzer şekilde kamu iç borçlanmasında ortaya çıkacak bir azalmanın gelir eşitsizliği üzerinde anlamlı ve negatif bir etkiye sahip olduğu sonucuna varılmıştır. Kısacası ele alınan dönem itibariyle Türkiye'de kamu iç borçlanmasındaki azalmanın gelir eşitsizliğini azalttığı tespit edilmiştir.

Anahtar Kelimeler: Kamu İç Borçlanması, Gelir Eşitsizliği, NARDL Uygulaması

The Asymmetric Effect of Domestic Public Debt on Income Inequality in Turkey

Abstract: This study investigated the asymmetric effects of domestic public debt on income inequality in Turkey. For this purpose, the Non-linear Autoregressive Distributed Lag (NARDL) model was preferred, which enables the determination of asymmetric effects between the series using the 1980-2015 annual data. In the context of empirical analysis, income inequality was used as the dependent variable. Within the scope of the main explanatory variable, domestic public debt was used. The economic growth, foreign direct investments and trade openness variables were used as control variables. The results showed that there is an asymmetrical relationship in the long term and symmetrical in the short term between income inequality and domestic public debt. It was determined that a negative shock in domestic public dept in the long term had a statistically significant and negative effect on income inequality. Similarly, it was concluded that a decrease in domestic public dept in the short term has a significant and negative effect on income inequality. The reduction in domestic public debt in Turkey for the discussed time period has been found to reduce income inequality.

Keywords: Domestic Public Dept, Income Inequality, the NARDL Application

${ }^{I}$ Dr. Öğr. Üyesi, İktisadi ve İdari Bilimler Fakültesi, Maliye Bölümü, Bütçe ve Mali Planlama Anabilim Dall, https://orcid.org/0000-0002-8084-4136 


\section{EXTENDED SUMMARY}

\section{Research Problem}

The purpose of this study, to investigate the effects of domestic public debt on income inequality in Turkey through an econometric model, which is a Non-linear Autoregressive Distributed Lag (NARDL) method.

\section{Research Questions}

In what ways does domestic public debt affect income inequality? What is the trend of domestic public debt and the income distribution in Turkey over the years? How can the negative effects of domestic public debt on income distribution be reduced or eliminated?

\section{Literature Review}

Various empirical studies have been conducted in different periods on the effects of internal and external public debt on macroeconomic variables such as investment, inflation, economic growth, interest rates and income inequality. In those studies, it is seen that there is a focus relation between the debt and variables such as economic growth, inflation, and interest rates. It can be said that the general conclusion found in international and national studies investigating the effects of domestic public debt on income inequality is the fact that domestic borrowing leads to an increase in the level of income inequality in the country concerned. Accordingly, some of the data obtained as a result of empirical analysis show that this effect is severe, while others reveal that there is a limited effect. The direction and severity of this effect may vary from country to country, depending on which income group the domestic government bonds are bought. Since determining the effect in question requires a long-term analysis, it is seen that empirical analysis is carried out mostly in the studies using the time series method.

\section{Methodology}

In this study the effect of public debt on income inequality during 19802015 in Turkey was examined. For this purpose, an empirical analysis was carried out using annual data of the relevant period. The household income inequality index series, which represents the income inequality variable (INEQ) included in the model,was used to as the dependent variable. The variable values are the index developed by Galbraith and Kum (2005) within the scope of the University of Texas Inequality Project (UTIP). They are estimated Gini coefficients panel based on a simple model.

The data were taken from the University of Texas website. Net borrowing series were used to represent the domestic public debt variable, which is the independent variable. Data about the variables were obtained from the database of the department of Strategy and Budget in the Presidency of the Republic of Turkey. In addition, control variables as economic growth, foreign direct investment and trade openness were included in the econometric model as other determinants of income inequality. Data on control variables were obtained from the World Bank Development Indicators database. After determining the 
order of stationarity of the series depending on the functional relationship created, the NARDL model was used to investigate asymmetric relationships between the variables.

\section{Results}

In the study, after determining the asymmetric relationship between variables through the Wald test and the cointegration relationship, long and short-term asymmetric coefficients were estimated. The findings showed that the decrease in domestic public debt or a negative shock in the long term has a negative effect on income inequality. In addition, it was seen that positive shock did not have any significant effect on income inequality. In the short term, it was found that a decrease in domestic public debt or a negative shock had a statistically significant and negative effect on income inequality, but an increase or positive shock did not have any significant effect. In short, it is concluded that the decrease in public domestic debt in the short and long-term reduces income inequality. In addition, it was observed that the increase or decrease in the economic growth variable included in the model as a control variable did not have any statistically significant effect on income inequality in the long term. It was learned that an increase in foreign direct investments, another variable of control, increased income inequality in the long term. Finally, it was found that both increase and decrease in trade openness reduced income inequality in the short and long term. According to this, it is seen that most of the findings obtained from the econometric analysis made in the study are consistent with the theoretical evaluations and empirical results in the literature.

\section{Giriş}

Kamu borçlarının ekonomik ve sosyal etkileri borcun kaynağı, türü, vade ve faiz oranında göre değişmektedir. Borçlanmanın gelir dağılımı üzerindeki etkileri ise borçlanma döneminde ortaya çıkan gelir ve servet gibi dolaysız olabileceği gibi; enflasyon, ekonomik büyüme ve faiz oranlarını etkileyerek dolaylı şekilde de olabilmektedir.

Kamu borçlanmasının gelir dağılımını etkilemesi beklenen çeşitli kanallar vardır. Bunlar: kamu borçları için faiz ödemelerinin yapılması; borçlanma yoluyla elde edilen gelirlerin sosyal transferler yoluyla topluma aktarılması ve söz konusu borçların ödenmesi için toplumun farklı gelir gruplarından vergi alınmasıdır. Ayrıca devlet borçlanması sonucunda kamu harcamalarının artmasına bağlı olarak enflasyonist etkilerin ortaya çıkması durumunda paranın değeri düşmektedir. Bunun sonucunda da devlet tahvili alıp faiz geliri elde etme imkanı olmayan düşük gelir gruplarının aleyhine gelir dağılımı bozulabilmektedir.

Kamu borçlarının gelir dağılımı üzerindeki etkisi daha çok borçların vade sonunda anapara ve faizi ile birlikte ödenmesi aşamasında görülür. Kamu kesimine ait borçlanma senetleri genellikle yüksek gelirli, marjinal tasarruf eğilimi yüksek sınırlı sayıda kişiler tarafından talep edilmektedir. Ödeme 
gücüne sahip herkesten toplanan vergi gelirlerinin, kamunun borçlanma senetlerini elinde bulunduran yüksek gelirli kişilere faiz geliri olarak aktarılması gelir dağılımında adaletsizliğe yol açmaktadır. Özellikle harcamalardan alınan dolaylı vergilerin toplam vergi gelirleri içindeki payının yüksek olduğu Türkiye gibi az gelişmiş ülkelerde tüketim eğilimi yüksek, dar gelirlilerden alınan vergilerin yüksek gelirlilere borç anapara ve faiz olarak ödenmesi gelir dağılımı üzerinde negatif bir etki meydana getirmektedir. Yani kamu borçlanmasından faiz geliri elde eden yüksek gelir sahibi kişiler ile bu borçların geri ödenmesi için toplanan vergileri ödeyen kişiler farklı oldukları sürece, gelirin negatif anlamda yeniden bölüşümü sorununa yol açan etkiler kendini göstermektedir. Ancak vergi ödeyenler ile devlet borçlanma senetlerini elinde bulunduranların aynı kişiler olması durumunda, devlet borçlanmasının gelir dağılımı üzerindeki bir etkisinden söz edilemez.

Devlet borçlanmasının sonucunda bu borçlardan faiz geliri elde edenlerin ne şekilde vergilendirildikleri, söz konusu borçlanmanın gelir dağılımı üzerinde yaptığı etkinin yön ve büyüklüğü üzerinde belirleyici olmaktadır. Borçlanma senetlerinin sahip olduğu yüksek faiz oranları ile vergi kanunlarındaki hazine bonosu ve devlet tahvillerine uygulanan düşük vergi oranları, muafiyet ve istisnalar da gelir dağılımı üzerinde önemli etkiye sahiptir. Ayrıca kamu borçlanmasındaki yüksek faiz ve diğer menfaatler, fonların yatırımlara yönelmesini önleyerek, istihdam ve ekonomik büyüme üzerinde de olumsuz etkilere neden olabilmektedir.

Enflasyonun yüksek olduğu dönemlerde yapılan borçlanma da gelir dağılımını olumsuz etkilemektedir. Yüksek faiz oranları ve vergi yükü nedeniyle devlet, vergi mükelleflerinden borçlanma senetlerine sahip olanlara doğru daha fazla kaynak transferi yapmaktadır. Bu durum gelir dağılımındaki bozulmayı şiddetlendirmektedir.

Türkiye'deki ekonomik yapı incelendiğinde, uzun yıllar yüksek oranlı şekilde varlığını devam ettiren enflasyon olgusunun gelir dağılımını bozan temel etmenlerin ilk sırasında yer aldığı söylenebilir. Özellikle 2000'li yılların başına kadar süren "çok yüksek oranlı" denilebilecek enflasyon sorunu, düşük ve sabit gelirli kişilerin reel gelirlerinin hızlıca erimesine sebebiyet verirken, söz konusu bu alt gelir grubunda yer alanların milli gelirden aldıkları payları da aşındırmıştır. Türkiye'de gelir dağılımına olumsuz etki eden başka bir önemli gelişme de, yıllar içerisinde iç borçlanma miktarının yüksek seviyede seyretmesi sonucunda devlet hazinesinin yüksek düzeyde reel faiz ödemek zorunda kalmasidır.

Özellikle reel faiz oranlarının ekonominin büyüme oranının üzerinde olduğu dönemlerde, iç borç faiz ödemelerinin gelir dağılımı üzerindeki olumsuz etkisi kaçınılmaz olmaktadır. Türkiye'de özellikle 1990'lı yıllarda reel faiz oranları GSYH artış oranlarının üzerinde seyretmiştir. Bu durum, devlet tahvili sahiplerinin elde ettikleri faiz gelirleriyle gelir dağılımından aldıkları payın artmasına neden olurken, devlet tahvili sahibi olmadığ 1 için faiz geliri elde 
edemeyenlerin ise gelir dağılımından aldıkları payın azalmasına neden olmuştur. $\mathrm{Bu}$ dönemde kronik hale gelen büyük bütçe açıklarının adaletli bir vergi düzeni ile finanse edilmesi yerine, yoğun borçlanma ile kapatılmaya çalışılması gelir dağılımındaki adaletsizliği daha da artıran bir unsur olmuştur.

Bu çalışmada Türkiye'de kamu iç borçlanmasının gelir dağılımı üzerine etkisi incelenmektedir. Çalışmada öncelikle devlet borçlanmasının tarihi ve teorik çerçevesi ele alınmıştır. Ardından iç borçlanmanın gelir dağılımı üzerine yaptığı etkiyi konu edinen teorik ve ampirik çalışmaların incelendiği literatür taraması yer almaktadır. Daha sonra ekonometrik analiz yapılmış ve çalışma bu ekonometrik analizin sonuçlarının da irdelendiği sonuç ve değerlendirme başlı̆̆ ile neticelendirilmiştir.

\section{Devlet Borçlanmasının Tarihi ve Teorik Çerçevesi}

Devlet borçlanması ve bunun etkileri konusunda iktisat tarihinde farklı akımlara mensup düşünürler ve yazarlar çeşitli görüşler ortaya koymuşlardır. $\mathrm{Bu}$ görüşler bazen birbiriyle örtüşebildiği gibi, bazen de çeşitli saiklerle birbirlerinden farklılaşabilmektedirler.

Merkantilist iktisadi akımına mensup olan ve devlet borçlanması konusuna ilk değinen yazarlardan J. Bodin, borcun devletin mali yapısında yıkıcı etkilere yol açacağına vurgu yaparak devletin borçlanmasına karşı çıkmıştır. (Dyson, 2014: 71-72). Merkantilist düşünce akımını sürdüren bir diğer düşünür olan J. F. Melon ise devlet borcunun ülkenin ekonomik kalkınması için yararlı olduğunu ifade etmiştir. Melon, borçlanmanın ticaret yapan her ülke için kesinlikle gerekli olduğunu ve devletin yürütmüş olduğu borç ilişkisinin "sağ elin sol ele borç vermesi" şeklinde olduğunu dile getirmiştir. (Bullock, 1920: 836-840; Salsman, 2017: 34). Bir diğer merkantilist iktisatçı C. Davenant, devlet borçlanması konusunda kapsamlı ve sistematik görüşleriyle bilinmektedir. Davenant, borçlanmanın borcun vadesi doluncaya kadar borçlu birey ya da topluma birtakım avantajlar sağlayacağını ve borcun alınmasından ödenmesine kadar geçen sürede borcun paranın üstlendiği fonksiyonu yerine getireceğini ifade etmiştir (Davenant, 1710: 2-3). Davenant'a göre, borçlanma kısa dönemde ihtiyaç duyulan finansmanın sağlanması için iyi bir alternatif olabilir. Ancak bu kaynağa sık sık başvurulması paranın ticaretten çekilmesine yol açarak ekonomide olumsuz etkilere neden olabilir (Matsushita, 1929: 13).

Fizyokrasi iktisadi akımının öncüsü F. Quesnay, yatırımlar ve sermaye büyümesi üzerinde yüksek faiz oranlarından ya da verimsiz borçlardaki rekabetin neden olduğu dişlama etkisinden kaynaklanan kısıtlamaları eleştirmiştir. Quesnay'a göre, tarım dışındaki sektörler verimsizdir ve borçlanma ile ilgili temel sorun rekabetten ziyade borçlanmanın bu verimli sektörü etkilemesidir. Yüksek faiz oranının neden olduğu etkiler, vergilerin borçlular, tarım sektörü ya da toplumun diğer kesimleri üzerinde neden olduğu etkilerden farksızdır. Bu nedenle, Quesnay başta olmak üzere fizyokratlar ödünç 
verme ya da borç alma özgürlügünü kısıtlayan faiz yasalarını savunmuşlardır (Rothbard, 2006: 373). Bir diğer fizyokrat düşünür olan R. J. Turgot, Quesnay' in aksine, yüksek faizi kısıtlayan yasaları kesin ve sert bir şekilde eleştirmiştir. Borçlunun para talebi üzerine alacaklının faiz karşııı̆ı̆nda ona borç vermesini, borçlunun zor durumundan yararlanma şeklinde görerek alacaklıya saldırmayı absürt bir argüman olarak nitelendirmiş ve bunu, "sattı̆̆ 1 ekmeğe para isteyen bir firıncının, müşterinin ekmek ihtiyacından yararlandığı"nı söylemeye benzediğini ifade etmiştir (Rothbard, 2006: 398).

Klasik iktisadi akıma mensup yazarlar devlet borçlanması konusunda muhafazakâr bir tutum sergilemişlerdir. Borçlanmanın hükümeti israfa sevkettiği düşüncesinden hareketle klasikler, borçlanmanın olağanüstü dönemlerde başvurulması gereken bir kaynak olması gerektiğini ifade etmiş̧lerdir. A. Smith, Milletlerin Zenginliği adlı kitabının 'Devlet Borçları Üzerine' ismini verdiği bölümünde, devletin gelirleri ile giderlerinin birbirine eşit olmasını savunmuş ancak savaş gibi olağanüstü durumlar baş gösterdiğinde devlet borçlanması yoluna gidilmesi gerektiğini ifade etmiştir (Smith, (1776)2007: 708-709). Önceki dönemlerde borçlanma hakkında yapılan "sağ elin sol ele borç vermesi" tabirinin tamamen ticari bir mantık üzerine kurulduğunu eleştirel bir şekilde ele almıştır. Borçlanma yoluyla sermayenin verimli alanlardan verimsiz alanlara aktarılacağını ve özel kesim sermayesinin zarar göreceğini ifade eden Smith, borçlanmaya karşı mesafeli bir tutum sergilemiştir. Bir diğer klasik iktisatçı Fransız J. B. Say, devlet borcu ile özel borç arasında büyük bir fark olduğunu belirtmiş ve bireylerin üretken bir nedenle borç almasına karşın, devletin üretken olmayan amaçlar için borç aldığını ifade etmiş̧ir. Say'a göre, devlet borçlanması üretken olmadığı gibi, devleti faiz ödeme yükümlülüğü ile karşı karşıya bırakmaktadır. Devlete borç olarak verilen fonlar, verimsiz alanlarda kullanıldığı için tüketilmekte ve herhangi bir gelir getirmemektedir (Say, (1821)-1971: 477). Say’a göre, borçlanmanın makul görülebileceği tek durum, ekonomideki âtıl kaynaklardan yatırımların finansmanı için yapılan borçlanmadır (Say, (1821)-1971: 479).

Klasik iktisat akımının önemli yazarlarından olan D. Ricardo, kendisinden öncekilerin ve çağdaşlarının vergiler yoluyla aşırı borç servisi gerçekleşmelerinin yurtdışına sermaye kaçışına yol açacağı yönündeki devlet borcu ile ilgili endişelerine katılmıştır. 1820 yılında kaleme aldığı "Finansman Sistemi Üzerine Deneme/Yazl" adlı eserinde devlet borcunun "bir ulusa zarar vermek için icat edilen en korkunç felaketlerden biri" olduğunu ifade etmiştir. Kamu harcamaları ister vergi isterse borçla finanse edilsin kaynaklar özel sektörden çekilmekte ve toplumsal refah kayba uğramaktadır (Salsman, 2017: 30). Ricardo'nun borçlanma teorisi "Ricardian Denklik Teorisi" şeklinde formüle edilerek literatürde oldukça geniş yer bulmuştur. Devletin yapmış olduğu bir harcamayı yeni bir borçla finanse etmesi durumunda insanlar yeni devlet borcunu ertelenmiş vergiler olarak algılayacaklar ve gelecekte ödenecek yükümlülükleri karşılamak üzere daha fazla tasarruf edeceklerdir. Ricardo, 
kamu harcamalarını finanse etmek için bugün alınan verginin, borç almanın ve bu borçların gelecekte faizi ile ödenmesinin bugünkü değerine eşit olduğunu ifade etmiştir (Salsman, 2017: 31). Ona göre, ilave kamu harcamalarının vergiler ya da borçlanma ile finansmanının etkisi nötr olacaktır.

Çalışmalarında devlet borçlanmasına değinen bir diğer düşünür Karl Marx’tır. Komünist iktisadi akımın öncüsü kabul edilen Marx'a göre, işçiler siyaset alanında kapitalistlerden daha az pazarlık gücüne sahiptirler. Devletler, sahip oldukları borçların ifası esnasında vergileri dolaylı veya dolaysız yollarla artırma yoluna gittiklerinde emek üzerinden alınan vergilerde artış meydana gelecektir. Marx, devletin gereken mali ihtiyacı karşılayacak yeni vergileri zengin sınıfa yüklemesi gerektiğini ileri sürmüştür. Ayrıca devlet borçlarının doğası gereği karmaşık ilişkiler ağına sahip olduğunu ve devlet borcunun gelecek nesiller üzerinde yük oluşturduğunu belirtmiştir. Bu kapsamda Marx, devlet borçlarını "hayali ve aldatıcl" bir sermaye kaynağı olarak nitelendirmiştir (Carcanholo, 2017: 304).

Klasik iktisadi teori, devlet bütçesinin küçük olmasını ve ekonomi içerisinde kontrollü kullanımını önerirken, Keynesyen teori ise makro ekonominin yönetiminde devlet bütçesine büyük önem vermektedir. J. M. Keynes'in kurduğu ekonomi anlayışında devlet bütçesinin denk olması gerekmez. Zira ekonomi eksik istihdamda kabul edilmektedir ve bu bağlamda makro ekonomik dengelerin sağlanabilmesi için de devlete ihtiyaç vardır. İstenilen ekonomik hedeflere ulaşılabilmek, ancak devletin maliye politikası uygulamalarıyla mümkündür. Yani Keynesyen yaklaşım devlete ve dolayısıyla da devlet bütçesine önem vermektedir. Keynesyen iktisatçılara göre, devlet borçlanmasıyla elde edilen gelirler gelecekte kendini finanse edecek yatırımlar için kullanıldıklarında, bu borçların gelecek nesiller üzerinde herhangi bir mali yük oluşturması söz konusu değildir. Aksi durumda, yani borçlanmadan elde edilen kaynaklar cari harcamalar için kullanıldıklarında ise, devlet borçlanması gelecek nesiller için bir yük anlamına gelebilecektir (Aspromourgo, 2018: 494). Ayrıca Keynesyen teoriye göre, devlet boçlanması ile yapılan harcamalar ya da uygulanan mali politikalar, gelecek nesillerin daha iyi şartlarda yaşamalarına olanak sağlamaktadır. Gelecek nesiller ise kendilerine sağlanan bu olanakların karşılığı olarak, önceden alınmış borçların sadece faizleri kadar bir ek yük üstlenmiş olacaklardır (Aspromourgo, 2018: 495).

Neoklasik iktisadi modelde, ekonominin tam istihdamda olduğu kabulü altında bütçe açıklarının tahvil ihracı ile karşılanması reel faiz oranlarının artması sonucunu doğuracaktır. Reel faiz oranlarının yükselmesi de özel sektör yatırımlarının azalmasını (dışlama- crowding out ${ }^{2}$ ) beraberinde getirecektir.

\footnotetext{
${ }^{2}$ Crowding out (dışlama) hipotezine göre, devletin kamu harcamalarının finansmanı için borçlanmaya başvurması özel kesim yatırımlarının azalmasına yol açmaktadır. Şöyle ki, devletin borçlanmaya başvurması, ödünç verilebilir fon talebini arttırarak faiz
} 
Neoklasik yaklaşıma göre ayrıca bütçe açıklarının borçlanmayla finansmanı yoluna gidilmesi, borçlanan neslin ölmesi sonucu gelecek nesiller üzerine anapara ve faiz ödemesi şeklinde bir yük olarak devrolacaktır (Bernheim, 1989: 56-57). $\mathrm{Bu}$ nedenlerle neoklasik iktisat yanlıları devlet borçlanmasına karşı çıkmışlardır.

Monetarist iktisat akımının öncüsü kabul edilen M. Friedman eserlerinde Keynesyen maliye politikasını eleştirmiş, ekonominin temelinde para politikasının var olduğunu savunmuştur. Monetaristler, Keynesyen iktisatçıların aksine devletin ekonomiye müdahalesinin gereksiz olduğu düşüncesindedirler. Monetaristler maliye politikasının tam dışlamaya (crowding out) yol açması sebebiyle etkinsiz olduğunu, dolayısıyla borçlanmaya gerek olmadığını savunmuşlardır. Monetarist yaklaşım, Keynesyen yaklaşımın savunduğu aktif maliye politikası görüşünün aksine durgun bir politika önermişler, vergilerin ve kamu harcamalarının kaynak dağılımının etkinliğini sağlayacak şekilde olmasını öngörmüşlerdir (Parasız, 2013: 342). Maliye politikası araçlarında öne çıkan borçlanma, klasik yaklaşımda olduğu gibi monetarist yaklaşımda da bütçe açılarının finanse edilmesinde arzu edilmeyen bir kaynaktır.

Arz yönlü iktisat yaklaşımına göre kamu harcamalarının artması bütçenin açık vermesine neden olarak ekonomide enflasyonist etkiye yol açmaktadır. Enflasyonist etkinin ortadan kaldırılması için denk bütçe politikası uygulanmalı veya vergi oranları düşürülmelidir. Aynı zamanda para politikası uygulanırken de vergi politikası ile orantılı şekilde uygulanırsa, enflasyonu aşağı düzeye çekebilecektir. Bu yaklaşıma göre, maliye politikası araçlarından borçlanmanın, kamu harcamalarının finansmanında kullanılması faiz oranlarını arttıracak ve özel yatırımın azalmasına sebep olacaktır. Yatırımların azalması da dolaylı olarak ekonomik büyümenin azalmasına yol açacaktır. Borç sorununun ülkelerin büyümesini olumsuz yönde etkilemesi, enflasyon ve işsizliğe sebep olması nedeniyle arz yönlü iktisatçılar borçlanmayı sakıncalı bulmaktadırlar (Parasız, 2013: 376). Bu yaklaşıma göre devlet borçlanması sadece ekonomik istikrarsızlıkların fazla olduğu durumlarda başvurulacak bir finansman kaynağ 1 olmalıdır.

J. Buchanan'ın öncülük ettiği kamu tercihi teorisyenleri, siyasilerin ve bürokratların fayda maksimizasyonu yapma saikleriyle sürekli etki alanlarını genişletme içinde olduklarını ileri sürmektedirler. Siyasilerin ve bürokratların bu davranışları ile baskı ve çıkar gruplarının faaliyetleri devletin büyümesi sonucunu doğurmaktadır. Ayrıca Keynesyen iktisadın savunduğu "gerektiğinde açık bütçe politikası uygulanmalı" anlayışı devletin ekonomi içerisindeki payını artırmaktadır. Oysa kamu tercihi ve anayasal iktisat yaklaşımına göre, devlet idari ve mali anlamda küçük olmalı ve devlet bütçesi de denk olmalıdır (Buchanan, 1959: 184). Bu akım savunucuları, sadece olağanüstü durumlarda

oranlarının yükselmesine yol açmaktadır. Faiz oranlarının artması sonucu yatırımların riskli hale gelmesi özel kesim yatırımlarını azaltmaktadır (Bilgili, 2010: 171). 
bütçe açığı ve borçlanmanın söz konusu olması gerektiğini ileri sürmektedirler. Ancak bunun tek şartı borç miktarının düşük olması ve kısa sürede kapatılmasidir.

\section{Literatür Araştırması}

Kamu iç ve dış borçlanmasının yatırımlar, enflasyon, ekonomik büyüme ve gelir dağılımı gibi bazı makroekonomik değişkenler üzerine etkilerini konu edinen çeşitli ampirik çalışmalar yapılmıştır. Yapılan çalışmaların daha çok borçlanmanın ekonomik büyüme, enflasyon ve yatırımlar gibi değişkenlere etkileri üzerinde yoğunlaştığı görülürken, bir kısım çalışmalar ise borçlanmanın gelir eşitsizliğine etkilerini konu etmektedir. Kamu iç borçlanmasının gelir eşitsizliği üzerine etkilerini konu edinen uluslararası nitelikteki çalışmalardan bazıları şunlardır:

Kurz ve Rall (1983), Almanya'da devlet borcunun kuşaklar arası ya da aynı kuşağın farklı gelir grupları arasında gelir transferine yol açtığı hipotezine dair ampirik bir çalışma yapmışlardır. Çalışmada, Alman Federal İstatistik Ofisi'nin 1978'deki gelir ve gider örnekleme anketinden (EVS) veriler kullanılmıştır, ancak veri eksikliğinden dolayı geniş kapsamlı varsayımlar yapmak zorunda kalmışlardır. Yaptıkları ampirik hesaplamalara dayanarak, devlet borçlarının aynı kuşağın alt gelir gruplarından üst gelir gruplarına doğru bir miktar gelir transferine yol açtığını belirtmektedirler. Ancak, hesaplamalarının çok sayıda tartışmalı varsayımlara dayandığı belirtilmelidir.

ABD için farklı bir sonuç Michl (1991) tarafindan ortaya konulmuştur. 1980'lerin başında en yüksek gelirli nüfusun yüzde birinin, vergi ödemelerinin toplam yüzde 11,2 ila 14,6'sını oluşturduğunu, ancak tüm devlet faiz ödemelerinin yüzde 22,5 ila 33,3'ünü aldığını belgelemiştir. Michl'in çalışması, devlet borcunun transfer yaklaşımı temelinde, gelirin (olumsuz anlamda) yeniden dağıtma etkisini teyit etmektedir.

Jong ve Dutt (1996) kamu borçları, gelir dağılımı ve ekonomik büyüme adlı çalışmalarında kamu borçlarındaki artışın ekonomide genişletici bir etki yarattığını, ancak özel sektör yatırımlarını dışlaması nedeniyle ekonomik büyümeyi ve gelir dağılımını ise olumsuz etkilediğini ifade etmişlerdir.

Loko vd. (2003), çalışmalarında devlet borçlanmasının özel sektör yatırımlarını düşürücü etkisiyle ekonomik büyümeye olumsuz etkilerinin yanında, kamu sosyal harcamaları üzerindeki olumsuz etkisinden de söz etmiş̧lerdir. Yazarlara göre sosyal harcama konusunda devletin bütçe tahsisleri yüksek borç servisi tarafından engellenmektedir. Bu durum da devletin eşitsiz gelir dağılımını iyileştirici politikalarını zora sokmaktadır.

Bilbiie vd. (2013), çalışmalarında kurdukları modelde, kamu borcunun fiyatların esnek veya yapışkan olmasına bağlı olarak yeniden dağıtma etkisi olabileceğini göstermektedirler. $\mathrm{Bu}$ modelde yapışkan fiyatlar ile kamu borcunun yeniden dağıtma etkileri ve tüm ekonomi için genişleyici etkileri vardir. 
Salti (2015), gelir eşitsizliğinin belirleyicileri ve kamu borcu ve borç kompozisyonunun rolü hakkında Lübnan üzerine yaptı̆̆ çalışmanın sonuçları iki önemli bulguyu göstermektedir: Birincisi, kamu borcunun seviyesi gelir eşitsizliği ile anlamlı ve pozitif olarak ilişkilidir ve ikincisi de iç piyasada bulunan borcun toplam kamu borcundaki payı gelir eşitsizliği ile önemli ve pozitif olarak ilişkilidir.

Akram ve Hamid (2016), güney Asya ülkeleri üzerine yaptıkları çalışmalarında kamu borçlanması, gelir eşitsizliği ve bunlara yönelik uygulanan makroekonomik politikaları ampirik analiz ile araştırmışlardır. Yazarların çalışmalarından elde ettikleri bulgulara göre, kamu dış borçlanması ile gelir dağılımı arasında herhangi bir iliş̧i bulunmazken, kamu iç borçlanması ile gelir dağılımı arasında negatif bir ilişki söz konusudur. Yani kamu borçlanmasında yaşanan artışlar, gelir eşitsizliğini artırmaktadır.

Kramer ve Anselmann (2016), kamu borçlarının gelir eşitsizliğini artırıp artırmadığını araştırdıkları çalışmalarında, devlet borcunun artırılmasıyla finanse edilen istihdam politikalarının, gelir ve servet eşitsizliğini daha da kötüleştireceğini ileri sürmektedirler. Yazarların çalışmadan elde ettikleri bulgular kamu iç borçlanmasının kuşak içi (intra-generational) gelir dağılımını bozucu etkilerinin, teorik ve ampirik literatürde yer alan yaygın görüşün ileri sürdüğü kadar, yüksek olmadığını göstermektedir.

Kamu iç borçlanmasının gelir eşitsizliği üzerine etkilerini konu edinen ulusal nitelikteki çalışmalardan bazıları ise şunlardır:

Akdiş'in (1995) çalışmasına göre, kamu iç borç anapara ve faiz ödemeleri alt gelir grubundan üst gelir grubuna bir gelir aktarımı olmakla kalmamakta, bu durum kamunun bir sonraki dönem borç ödemelerini de güçleştirmektedir. Zira vergi yükü ağırlaşan alt gelir grubunun vergi ödeme gücü bir sonraki dönem azalmaktadır. Bu durum da kamu borç ödemeleri için mali kaynă̆ın azalması anlamına gelmektedir.

Gökçen (2002) Türkiye ekonomisindeki borçları değerlendirdiği çalışmasında, iç borçların gelir dağılımını bozduğu sonucuna varmıştır. İç borç stokunun en önemli etkilerinden biri borç yüküdür. Reel faiz oranı bir ekonomideki büyüme oranının üstünde ise borç yükü artar. Buna göre borç yükü, GSMH' nin daha büyük bir kısmı haline gelecek ve faiz ödemelerinin yükünü artıracaktır. Bu durum gelir dağılımının bozulmasına ve kaynakların daha spekülatif amaçlar için kullanılmasına yol açmaktadır.

Bulut ve Canpolat'ın (2003) çalışmaları bütçe açı̆̆ı, enflasyon, faiz oranları, döviz kuru ve gelir dağılımının kamu borcu ile doğrudan ilintili olduğunu göstermektedir. Söz konusu çalışma yüksek düzeydeki faiz oranlarının borçlanma yükünü artırdığını ve adaletsiz gelir dağılımına neden olduğunu ortaya koymaktadır.

Çetin (2005) Ricardocu Denklik Teoremi'nin Türkiye için geçerli olup olmadığını yaptığı bir çalışma ile analiz etmiştir. Çalışmanın sonucuna göre Ricardocu Denklik Teoremi Türkiye için geçerlidir. Ayrıca bu çalışmasında 
Çetin, ekonomik büyüme için kamu borçlanmasının doğru bir yol olmadığını, büyümenin ve ekonomi politikasının daha etkin kılınmasının ancak bütçe açıklarının ve bunun sonucunda ortaya çıkan borçlanmaların azaltılmasına bağlı olduğunu ileri sürmektedir.

Ulusoy ve Cural (2006) da Türkiye'de 1980'den sonraki iç borçların sürdürülebilirliği konusundaki çalışmalarında, Türkiye'de sürdürülemez iç borçlanmanın mevcut olduğu sonucuna varmışlardır. Yazarlara göre, sürdürülebilir olmayan borç fiyat istikrarını bozmakta, ekonomik büyümeyi engellemekte ve uzun vadeli makro-ekonomik planlara ulaşılmasını zorlaştırmaktadır. Ayrıca İç borç stoku büyüklügünün, yüksek enflasyon ve gelir eşitsizliği dahil olmak üzere birçok makro-ekonomik sorunun nedenini oluşturduğu sonucuna varmışlardır.

Demir ve Server (2008) yaptıkları çalışmalarında kamu iç borcunun mevcut gelir dağılımı eşitsizliğini derinleştirdiğini iddia etmişlerdir. Yazarların çalışmadan elde ettikleri bulgulara göre söz konusu olumsuz etkiler borç faiz ve anapara ödemeleri sırasında ortaya çıkmaktadır.

Türkiye'de 1980 sonrası iç borçlanmanın ekonomik ve sosyal etkilerini araştıran Bayraktar (2009), kamu kesiminin yüksek faiz oranları ile piyasadan borçlanmasının özel sektöre fon sağlama olasılığını daraltdığını, dolayısıyla reel ekonominin olumsuz yönde etkilendiğini belirtmektedir. Çalışmaya göre, özellikle enflasyon dönemlerinde, takip edilen borçlanma politikaları, hükümetin alacaklısı olmayan sektörlere karşı gelir dağılımında ciddi bir bozulmaya yol açmaktadır.

Bedir ve Karabulut (2011) iç borçların gelir dağılımı üzerine etkileri konusunda yapmış oldukları çalışmalarında borçlanmanın başlangıçta devlete mali bir rahatlık sağladığı, ancak zaman içerisinde iç borçlardaki reel faiz oranlarının yüksekliği ve vadelerinin kısa olması nedeniyle gelir dağılımını bozucu bir etki yaptığı sonucuna ulaşmışlardır.

Sugözü vd. (2017) kamu borç faizi ödemelerinin gelir dağılımı üzerindeki etkilerini 2002-2015 dönemini kapsayan bir ampirik analizle araştırmışlardır. Yazarlar, gelir dağılımı üzerinde kamu iç borç faiz ödemelerinin yanında yüksek işsizlik oranı, dolaylı vergi gelirlerinin toplam vergi gelirleri içindeki payının yüksek oluşu ve yüksek enflasyon oranı gibi başka faktörlerin de olumsuz etkilerinin olduğunu ileri sürmektedirler. Çalışmadaki ampirik analizin sonucuna göre, kamu iç borç faiz oranlarında yaşanan azalma gelir dağılımını olumlu yönde etkilemektedir (iyileştirmektedir).

Arslan (2019) Türkiye'de kamu borçlanması ve gelir dağılımı ilişkisini araştırdığı çalışmasında, Türkiye'de 2000'li yıllardan sonra kamu borçlanma gereksiniminin giderek azaldığını ve buna bağlı olarak ta borçlanma faiz oranlarının yıllar içerisinde düştüğünü tespit etmiştir. Yazara göre, kamu borçlanmasından faiz geliri elde edenler üst gelir grubunda yer alan kişilerden oluşmaktadır. Çalışmadaki ampirik analizin sonucuna göre, kamu iç borçlanma miktarındaki azalma gelir dağılımı eşitsizliğini azaltmaktadır. 
Türkiye'de Kamu İ̧̧ Borçlanmasının Gelir Eşitsizliği Üzerindeki Asimetrik Etkisi

\section{Ampirik Analiz}

\subsection{Veri Seti ve Ekonometrik Yöntem}

Çalışmada Türkiye'de 1980-2015 döneminde kamu iç borçlanmanın gelir eşitsizliği üzerindeki etkisi incelenmiştir. Bu amaçla ilgili döneme ait yıllık veriler kullanılarak ampirik analiz gerçekleştirilmiştir. Bağımlı değişken olarak modele dahil edilen gelir eşitsizliği değişkenini(INEQ) temsilen hane halkı gelir eşitsizliği endeksi serileri kullanılmıştır. Değişkene ait değerler Texas Üniversitesi Eşitsizlik Projesi(UTIP) kapsamında Galbraith ve Kum (2005) tarafından geliştirilmiş endeks olup, basit bir modele dayanan tahmini Gini katsayıları panelidir. Veriler Texas Üniversitesi web sitesinden alınmıştır. Bağımsız değişken olan kamu iç borçlanması değişkenini(DEBT) temsil etmek üzere ise net borç kullanımı(net borrowing) serileri kullanılmışıı. Değişkene ait veriler Türkiye Cumhuriyeti Cumhurbaşkanlığı Strateji ve Bütçe Başkanlığına ait veri tabanından temin edilmiştir. Ayrıca ekonometrik modele gelir eşitsizliğinin diğer belirleyicileri olarak kontrol değişkeni niteliğindeki ekonomik büyüme (GROWTH), doğrudan yabancı yatırımlar(FDI) ve ticari dışa açıklık(TRADE) değişkenleri konulmuştur. Ekonomik büyümeyi temsilen yıllık reel GSYH artış hızı, doğrudan yabancı yatırımları temsilen ülkeye net doğrudan yabancı yatırım giriş miktarları ve ticari dışa açıklık değişkenini temsilen ise mal ve hizmet ihracat ve ithalat toplamının GSYH'ye oranı kullanılmıştır. Kontrol değişkenlerine ait veriler Dünya Bankası Kalkınma Göstergeleri veri tabanından elde edilmiştir. Kamu iç borçlanması ve doğrudan yabancı yatırımlar serileri doğal logaritmaları alınarak analize dahil edilmiştir.

Türkiye'de gelir eşitsizliği üzerinde kamu iç borçlanmasının etkisinin araştırılması için aşağıdaki fonksiyonel ilişki ele alınmıştır. $I N E Q=f(D E B T, G R O W T H, F D I, T R A D E)$

Oluşturulan bu fonksiyonel ilişkiye bağlı olarak ilk olarak serilerin durağanlığı araştırılmıştır. bu kapsamda ADF (Genişletilmiş Dickey Fuller), PP (Phillips-Perron) ve Zivot Andrews birim kök testleri kullanılmıştır. Serilerin durağanlık dereceleri tespit edildikten sonra değişkenler arasındaki asimetrik ilişkilerin araştırılması amacıyla NARDL (Non-linear Autoregressive Distributed Lag) modeli kullanılmıştır.

\subsection{Ampirik Analiz}

3.2.1 Birim Kök Testleri ve Sonuçlar

Zaman serisi verilerine dayanan çalışmalarda serilerin durağan olup olmadıklarının belirlenmesi sahte regresyon sorunun önüne geçmek için çok önemlidir. Bir zaman serisinin ortalama ve varyansı sabit olup, iki dönem arasındaki ortak varyansı hesaplandığı döneme değil iki dönem arasındaki uzaklığa bağlı ise serinin durağan olduğu söylenir. Bu özelliklere sahip olmayan verilerle yapılacak analizlerde yanıltıcı tahminler ortaya çıkabileceğinden sonuçların güvenilirliği sarsılmaktadır (Karaca, 2003: 249; Gujarati, 2004: 792). Değişkenler arasında katsayı tahminlerine geçmeden önce, ilk olarak ADF 
(Genişletilmiş Dickey Fuller) ve PP (Phillips-Perron) birim kök testleriyle serilerin durağanlığı sinanmıştır. Aşağıdaki Tablo 1'de ADF ve PP birim kök testi sonuçları yer almaktadır.

Tablo 1: $A D F$ and PP Birim Kök Testi Sonuçları

\begin{tabular}{|c|c|c|c|c|c|c|c|c|}
\hline & & & & INEQ & DEBT & GROWTH & FDI & TRADE \\
\hline \multirow{4}{*}{ ADF } & \multirow{8}{*}{ 䔍 } & \multirow[b]{2}{*}{ Düzey } & $t$ ist. & -1.275 & -1.650 & $-6.406^{a}$ & $1 . \overline{6} 66$ & -2.505 \\
\hline & & & Olasılık & 0.629 & 0.447 & 0.000 & 0.439 & 0.123 \\
\hline & & \multirow[b]{2}{*}{ 1. Fark } & $t$ ist. & $-4.006^{\mathrm{a}}$ & $-5.728^{a}$ & - & $\begin{array}{c}- \\
7.253^{\mathrm{a}} \\
\end{array}$ & $-5.514^{\mathrm{a}}$ \\
\hline & & & Olasılık & 0.004 & 0.000 & - & 0.000 & 0.000 \\
\hline \multirow{4}{*}{ PP } & & \multirow[b]{2}{*}{ Düzey } & $t$ ist. & -1.178 & -1.695 & $-6.454^{a}$ & $\begin{array}{c}- \\
1.706 \\
\end{array}$ & -2.568 \\
\hline & & & Olasılık & 0.673 & 0.425 & 0.000 & 0.419 & 0.109 \\
\hline & & \multirow[b]{2}{*}{ 1. Fark } & $t$ ist. & $-4.070^{\mathrm{a}}$ & $-5.727^{a}$ & - & $\begin{array}{c}- \\
7.820^{\mathrm{a}}\end{array}$ & $-6.861^{a}$ \\
\hline & & & Olasılık & 0.003 & 0.000 & - & 0.000 & 0.000 \\
\hline \multirow{4}{*}{ ADF } & \multirow{8}{*}{ 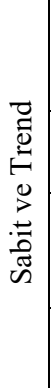 } & & $t$ ist. & -0.256 & -0.846 & $-6.331^{a}$ & $3 . \overline{347^{\mathrm{c}}}$ & $-3.431^{c}$ \\
\hline & & Düzey & Olasılık & 0.989 & 0.951 & 0.000 & 0.075 & 0.064 \\
\hline & & & $t$ ist. & $-4.298^{a}$ & $-6.237^{a}$ & - & - & - \\
\hline & & 1. Fark & Olasılık & 0.009 & 0.000 & - & - & - \\
\hline \multirow{4}{*}{ PP } & & \multirow[b]{2}{*}{ Düzey } & $\mathrm{t}$ ist. & -0.741 & -0.808 & $-6.374^{a}$ & $\begin{array}{c}- \\
3.347^{\mathrm{c}}\end{array}$ & $-3.202^{c}$ \\
\hline & & & Olasılık & 0.962 & 0.955 & 0.000 & 0.075 & 0.100 \\
\hline & & \multirow[b]{2}{*}{ 1. Fark } & $t$ ist. & $-4.300^{\mathrm{a}}$ & $-6.321^{a}$ & - & - & - \\
\hline & & & Olasılık & 0.009 & 0.000 & - & - & - \\
\hline
\end{tabular}

Not: $a, b$ ve c harfleri, sirasıyla $\% 1, \% 5$ ve $\% 10$ anlamlılık düzeylerini ifade etmektedir.

ADF testi için uygun gecikme uzunluğu Schwarz Bilgi kriteri ile belirlenirken, PP ve KPSS testleri için band genişliğinin belirlenmesinde Newey-West Bandwidth kriteri kullanılmıştır.

ADF ve PP birim kök testi sonuçlarına göre, INEQ ve DEBT serileri hem sabit hem de sabit ve trendli modele göre düzey değerlerinde durağan değil iken birinci farkı alındığında durağan hale gelmektedir. Yani değişkenlerin I(1) oldukları bulgusuna ulaşılmıştır. GROWTH serisi, hem sabit hem de sabit ve trendli modele göre durağan bir özellik sergilemektedir. Yani değişkenin $\mathrm{I}(0)$ olduğu tespit edilmiştir. FDI ve TRADE serileri ise sabitli modele göre birinci farkı alındığında durağan bir yapıya kavuşurken, sabit ve trendli modele göre düzey değerlerinde durağandır. Dolayısıyla her iki değişken sabitli modele göre I(1), sabit ve trendli modele göre ise I(0)'dır. Sonuç olarak ADF ve PP birim kök testlerine göre değişkenlerden bazılarının I(0) ve bazılarının I(1) olduğu belirlenmiştir.

ADF ve PP birim kök testlerinin serideki yapısal kırılmaları dikkate almamasından dolayı serideki olası yapısal kırılmalar durağanlık sınamasında 
önemli istatistiki sorunlar yaratabilmektedir. $\mathrm{Bu}$ nedenle yapısal kırılmayı dikkate alan Zivot-Andrews (ZA) birim kök testi de uygulanmıştır. Hesaplanan $\mathrm{t}$ istatistiğinin ZA kritik değerinden mutlak değerce küçük olması halinde trend fonksiyonunda meydana gelen bir yapısal kırılmayla birlikte serinin trend durağan olduğu ve kritik değerden mutlak değer olarak büyük olması halinde serinin birim köke sahip olduğu ifade edilebilir. Aşağıdaki Tablo 2'de ZA birim kök testi sonuçları sunulmaktadır.

Tablo 2: ZA Birim Kök Testi Sonuçları

\begin{tabular}{|c|c|c|c|c|c|c|c|}
\hline \multirow{2}{*}{ Değişkenler } & & $\begin{array}{c}\text { t ist. } \\
\text { Model A } \\
\text { (Sabit) }\end{array}$ & $\begin{array}{c}\text { Yapısal } \\
\text { Kırılma } \\
\text { Tarihi }\end{array}$ & $\begin{array}{c}\text { t ist. } \\
\text { Model B } \\
\text { (Trend) }\end{array}$ & $\begin{array}{c}\text { Yapısal } \\
\text { Kirılma } \\
\text { Tarihi }\end{array}$ & $\begin{array}{c}\text { t ist. } \\
\text { Model C } \\
\text { (Sabit ve } \\
\text { Trend) }\end{array}$ & $\begin{array}{c}\text { Yapısal } \\
\text { Kırılma } \\
\text { Tarihi }\end{array}$ \\
\hline \multirow{2}{*}{ INEQ } & Düzey & -3.446 & 1989 & -3.530 & 1995 & -3.359 & 1989 \\
\cline { 2 - 8 } & $\mathbf{1 . ~ F a r k ~}$ & $-5.178^{\mathrm{b}}$ & 1989 & $-4.811^{\mathrm{a}}$ & 1990 & $-4.903^{\mathrm{c}}$ & 1995 \\
\hline \multirow{2}{*}{ DEBT } & Düzey & -2.559 & 2005 & $-4.701^{\mathrm{b}}$ & 2002 & -4.325 & 2001 \\
\cline { 2 - 8 } & $\mathbf{1 . \text { Fark }}$ & $-7.653^{\mathrm{a}}$ & 2002 & - & - & $-7.383^{\mathrm{a}}$ & 2002 \\
\hline GROWTH & Düzey & $-6.773^{\mathrm{a}}$ & 2002 & $-6.487^{\mathrm{a}}$ & 2002 & $-6.684^{\mathrm{a}}$ & 2003 \\
\hline \multirow{2}{*}{ FDI } & Düzey & -4.011 & 2005 & -3.494 & 2008 & $-4.968^{\mathrm{c}}$ & 2005 \\
\cline { 2 - 8 } & $\mathbf{1 . ~ F a r k}$ & $-7.535^{\mathrm{a}}$ & 2008 & $-7.122^{\mathrm{a}}$ & 2006 & - & - \\
\hline TRADE & Düzey & $-5.857^{\mathrm{a}}$ & 1994 & $-4.563^{\mathrm{b}}$ & 1998 & $-5.691^{\mathrm{a}}$ & 1994 \\
\hline Kritik Değerler & & Model A & & Model B & & Model C & \\
\hline $\mathbf{1 \%}$ & & -5.34 & & -4.80 & & -5.57 & \\
\hline $\mathbf{5 \%}$ & & -4.93 & & -4.42 & & -5.08 & \\
\hline $\mathbf{1 0 \%}$ & & -4.58 & & -4.11 & & -4.82 & \\
\hline
\end{tabular}

Not: $a, b$ ve c harfleri, sirasıyla $\% 1, \% 5$ ve $\% 10$ anlamlılık düzeylerini ifade etmektedir.

ZA birim kök test sonuçlarına göre, INEQ serisi Model A, Model B ve Model C'ye göre düzeyde birim köke sahip olup, birini farkı alındığında durağan hale gelmektedir. DEBT değişkeni, Model A ve Model C'ye göre birinci farkı alındığında durağan hale gelir iken, Model B'ye göre seviye değerlerinde durağandır. FDI serisinin Model A ve Model B'ye göre birinci farkında durağan iken Model C'ye göre düzeyde durağan olduğu tespit edilmiştir. Ayrıca GROWTH ve TRADE serilerinin tüm modellere göre düzey değerlerinde durağan bir yapı sergiledikleri görülmüştür. Bu sonuçlara bağ ${ }_{1}$ olarak, değişkenlerin bazılarının düzey değerlerinde durağan ve bazılarının ise birinci farklarında durağan oldukları tespit edilmiştir. Çalışmanın bundan sonraki kısmında değişkenlerin bazıları $\mathrm{I}(0)$ ve bazıları I(1) olduğu durumda uygulanabilen analiz testleri kullanılmaktadır.

\subsubsection{NARDL Modeli ve Tahmin Sonuçlart}

Pesaran vd. (2001) değişkenlerin I(0), I(1) ya da aynı dereceden entegre oldukları durumda uzun dönem ilişkinin varlığını belirlemek için bir asimetrik eşbütünleşme ARDL modeli (NARDL) geliştirilmişlerdir (Shin vd. 2014, 1-10).

Aşağıdaki doğrusal olmayan uzun dönem ilişkiyi modellemek için alternatif bir yaklaşım ortaya koymuşlardır: 
$y_{t}=\beta^{+} x_{t}^{+}+\beta^{-} x_{t}^{-}+u_{t}$

$$
\Delta x_{t}=v_{t},
$$

$y_{t}$ ve $x_{t}$ birinci dereceden bütünleşik, I(1), değiş̧kenlerdir ve $x_{t}$ aşağıdaki şekilde bileşenlerine ayrilabilir:

$x_{t}=x_{0}+x_{t}^{+}+x_{t}^{-}$

$\mathrm{Bu}$ denklemde, $x_{t}^{+}$ve $x_{t}^{-}, x_{t}$ 'deki pozitif ve negatif değişimlerin kısmi toplamlarını belirtmektedir.

$$
x_{t}^{+}=\sum_{j=1}^{t} \Delta x_{j}^{+}=\sum_{j=1}^{t} \max \left(\Delta x_{j}, 0\right), \quad x_{t}^{-}=\sum_{j=1}^{t} \Delta x_{j}^{-}=\sum_{j=1}^{t} \min \left(\Delta x_{j}, 0\right)
$$

Denklem 1'in birinci farkını alınıp çeşitli dönüşümler yapılarak asimetrik eşbütünleşme ile ilişkili hata düzeltme modeli elde edilebilir:

$$
\begin{aligned}
\Delta y_{t}=\rho y_{t-1}+ & \theta^{+} x_{t-1}^{+}+\theta^{-} x_{t-1}^{-} \\
& +\sum_{i=1}^{p} \varphi_{i} \Delta y_{t-i}+\sum_{i=0}^{p}\left(\pi_{i}{ }^{+} \Delta x_{t-1}^{+}+\pi_{i}{ }^{-} \Delta x_{t-1}^{-}\right) \\
& +\varepsilon_{t}
\end{aligned}
$$

Denklem 3'ten yola çıkarak asimetrik uzun dönem katsayılar elde edilebilir. $\mathrm{x}$ değiş̧keninin y değişkeni üzerindeki asimetrik etkileri sırasıyla $\beta^{+}=-\theta^{+} / \rho$ ve $\beta^{-}=-\theta^{-} / \rho$ şeklinde belirlenmektedir (Shin vd. 2014, 1-10).

Ampirik analiz kapsamında ilk olarak denklem 3 tahmin edilip sonrasında eşbütünleşme ilişkisi incelenir. Bu amaçla Shin vd. (2014) tarafindan önerilen 2 yöntem kullanılır. Birincisi, $t_{B D M}$ olarak bilinen $t$ testi yaklaşımı ve İkincisi ise $F_{P S S}$ şeklinde adlandırılan $\mathrm{F}$ testi yaklaşımıdır. Değişkenler arasında eşbütünleşme ilişkisi olup olmadığ $\mathrm{t}$ testi yaklaşımı için Banerjee vd. (1998)'in çalışmasındaki tablolar kullanılarak belirlenir. F testi yaklaşımı için ise Pesaran vd. (2001)'in çalışmasındaki tablolar kullanılarak karar verilir. Her iki yaklaşımda da hesaplanan istatistik değerlerin tablo kritik değerlerden mutlak değer olarak büyük olması, eşbütünleşme ilişkisinin varlığını gösterir. Eşbütünleşme ilişkisinin varlığı belirlendikten sonra ilk olarak uzun ve kısa dönem asimetriler Wald testi yardımıyla aşağıdaki hipotezler test edilerek belirlenir:

Uzun dönem asimetri için $H_{0}: \theta^{+}=\theta^{-}$

Kısa dönem asimetri için $H_{0}: \pi_{i}^{+}=\pi_{i}^{-}$ya da $H_{0}: \sum_{i=0}^{p} \pi_{i}^{+}=\sum_{i=0}^{p} \pi_{i}^{-}$

Uzun ve kısa dönem asimetri/simetri durumu tespit edildikten sonra ise negatif ve pozitif uzun dönem parametreler elde edilebilir. Negatif ve pozitif uzun dönem parametreler için sıfır hipotezler sırasıyla $\beta^{+}=-\theta^{+} / \rho$ ve $\beta^{-}=$ $-\theta^{-} / \rho$ şeklindedir (Mert ve Çağlar, 2019, 314-315). Aşağıdaki Tablo 3 'te değiş̧kenler arasındaki simetri/asimetri durumlarının incelenmesi için uygulanan Wald testi sonuçları gösterilmiştir. 
Türkiye'de Kamu İ̧̧ Borçlanmasının Gelir Eşitsizliği Üzerindeki Asimetrik Etkisi

Tablo 3: NARDL Tahmin Sonuçları

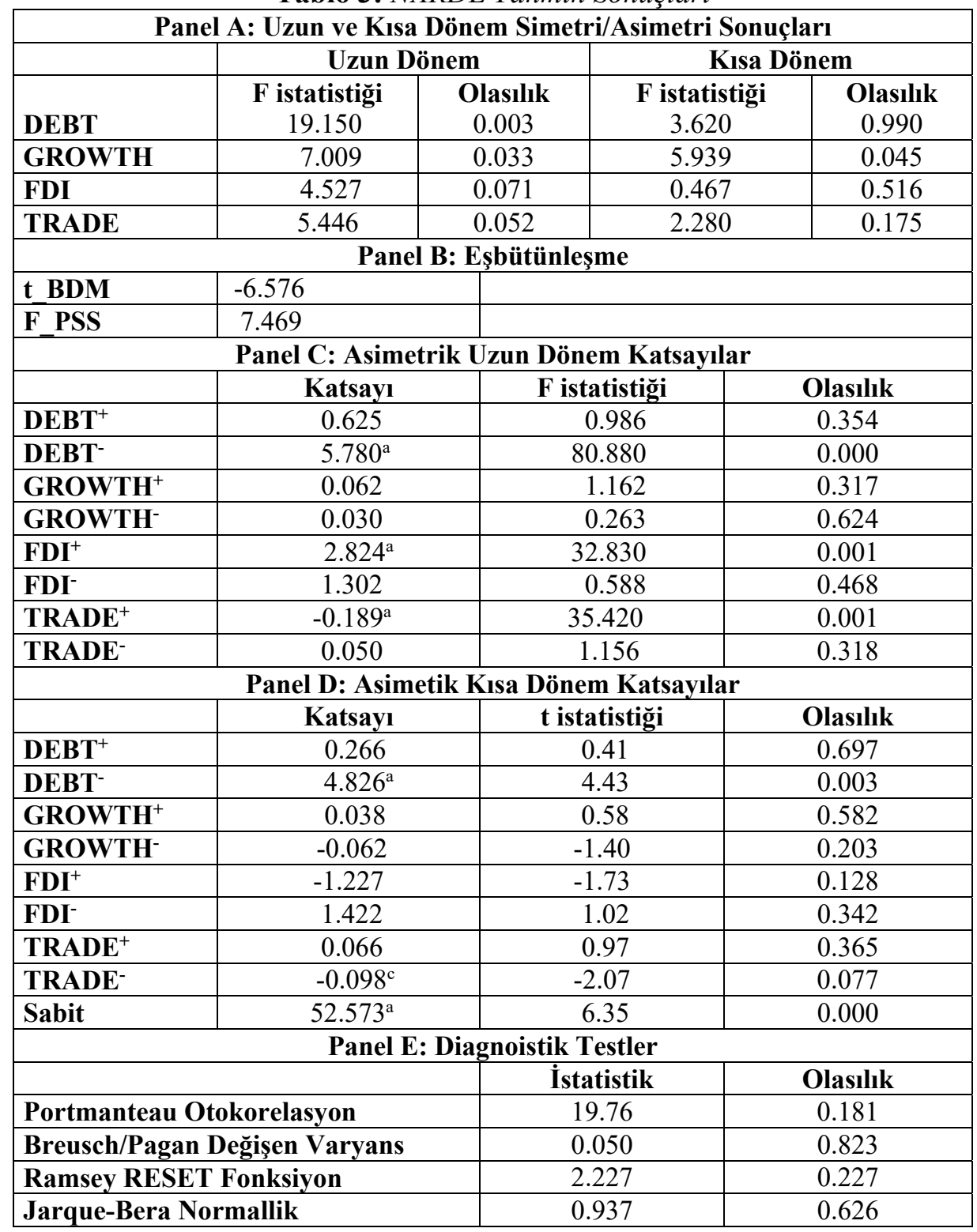

Not: $a, b$ ve c harfleri, sırasıyla $\% 1, \% 5$ ve $\% 10$ anlamlllık düzeylerini ifade etmektedir. t BDM istatistiği için $\% 1, \% 5$ ve $\% 10$ anlam düzeyinde kritik değerler sırasıyla $-5.79,4.56$ ve 4.04 'dir (Banarjee vd. 1996:11). F PSS istatistiği için \%1, \%5 ve \%10 anlam düzeyinde kritik değerler sırasıyla 4.40-5.72, 3.47-4.57 ve 3.03-4.06 olarak alınmıştır (Pesaran vd. 2001: 301)

Tablo 3'te A panelinde gösterilen sonuçlara göre, gelir eşitsizliği(INEQ) ile DEBT, GROWTH, FDI ve TRADE serileri arasında uzun dönemde simetrik 
bir ilişki olduğunu ifade eden sıfır hipotezi reddedilmiştir. Buna göre gelir eşitsizliği ile tüm bağımsız değişkenler arasında uzun dönemde asimetrik bir ilişkinin varlığı kanıtlanmıştır. Dolayısıyla DEBT, GROWTH, FDI ve TRADE değişkenlerinde meydana gelecek pozitif ya da negatif bir şokun gelir eşitsizliği üzerindeki etkisi asimetrik olarak gerçekleşmektedir. Kısa dönem sonuçları incelendiğinde ise sadece INEQ ile GROWTH serileri arasında asimetrik bir ilişki olduğu ancak INEQ ile diğer seriler arasında arasında simetrik bir ilişki olduğu belirlenmiştir. Kısacası çalışmanın temel açıklayıcı değişkeni olan gelir eşitsizliği ile kamu iç borçlanması arasında uzun dönemde asimetrik ve kısa dönemde simetrik bir ilişki olduğu belirlenmiştir. Buna bağlı olarak uzun dönem katsayı tahmini yapılırken asimetrik ilişkilerin göz önünde bulundurulması gerekmektedir.

Tablo 3'te B panelinde seriler arasında eşbütünleşme ilişkisinin olup olmadığına dair sonuçlar gösterilmiştir. Buna göre t_BDM değeri(-6.576) $\mathrm{k}=4$ için \%1 anlamlılık düzeyinde kritik değerlerden mutlak olarak büyüktür ve F_PSS değeri(7.469) $\mathrm{k}=4$ için $\% 1$ anlamlılık düzeyinde kritik aralık değerlerinden büyüktür. Sonuç olarak hem $t$ istatistiği hem de $F$ istatistiğine dayalı sonuçlar seriler arasında eşbütünleşme ilişkisinin varlığını kanıtlamaktadır. Panel E'de gösterilen model ile ilgili diagnoistik test sonuçları anlamlı çıkmıştır. Buna göre modelde otokorelasyon ve değişen varyans sorunu olmadığı belirlenmiştir. Ayrıca hata teriminin normal dağıldığı ve model kurma hatasının olmadığ 1 da tespit edilmiştir.

Panel C'de gösterilen asimetrik uzun dönem katsayı tahmin sonuçlarına

göre, çalışmanın temel açıklayıcı değişkeni olan kamu iç borçlanmasında(DEBT) meydana gelecek bir artı̧̧ ya da pozitif şokun gelir eşitsizliği üzerinde herhangi anlamlı bir etkiye sahip olmadığı bulgusuna ulaşılmıştır. Ancak kamu iç borçlanmasında meydana gelecek \%1'lik azalış ya da negatif bir şokun gelir eşitsizliğini uzun dönemde doğrusal yönlü olarak \%5.780 oranında azaltacağ 1 belirlenmiştir.

Kontrol değişkenlerinden biri olan ve ekonomik büyümeyi temsil eden GROWTH değişkeninde meydana gelecek artışın ya da azalışın uzun dönemde gelir eşitsizliği üzerinde istatistiki olarak herhangi anlamlı bir etkiye sahip olmadığı gözlemlenmiştir. Doğrudan yabancı yatırımları temsilen kullanılan FDI değişkenindeki bir artışın gelir eşitsizliğini istatistiki olarak anlamlı ve pozitif etkilediği ancak azalmanın istatistiki olarak anlamlı bir etkisinin olmadığı görülmüştür. Buna göre doğrudan yabancı yatırımlardaki \%1'lik artış gelir eşitsizliğini doğrusal olarak \%2.824 düzeyinde artırmaktadır. Son olarak ticari dışa açıklığı temsilen kullanılan TRADE değişkeninde meydana gelecek azalışın herhangi bir anlamlı etkiye sahip olmadığı tespit edilmiştir. Ancak değişkendeki bir artış ya da pozitif bir şokun gelir eşitsizliğini olumsuz etkilediği saptanmıştır. Buna göre ticari açıklıkta meydana gelecek \%1'lik artış ya da pozitif bir şok gelir eşitsizliğini aksi yönde \%-0.189 gibi çok küçük 
oranda azaltacaktır. Bu sonuçlar 1şığında gelir eşitsizliği üzerinde uzun dönemde en etkili değişkenin DEBT olduğu belirlenmiştir.

Panel D'de gösterilen asimetrik kısa dönem sonuçlarına göre temel değişken gelir eşitsizliğindeki (DEBT) bir artış ya da pozitif bir şokun gelir eşitsizliği üzerinde herhangi anlamlı bir etkisinin olmadığı belirlenmiştir. Ancak değişkende bir azalış ya da meydana gelecek negatif bir şokun pozitif ve anlamlı etkilere sahip olduğu sonucuna varılmıştır. Kontrol değişkenleri ele alındığında ise simetrik bir etkiye sahip ticari dışa açıklık değişkeni (TRADE) dıșında gelir eșitsizliği üzerinde anlamlı etkilere sahip olan bir değişken bulunmamaktadır. Kısa dönemde TRADE değişkenindeki bir azalmanın gelir eşitsizliğini azalttığı gözlenmiştir.

\section{Sonuç}

Bir devletin iç borçlanmaya gitmesi, bu borçların temin edildikleri kaynağa ve kullanıldıkları yerlere göre farklı etkilere neden olabilmektedir. Hükümetlerin yurtiçinden borçlanarak topladıkları fonları yatırımlarda kullanması halinde toplam yatırım hacmi değişmemekte, yatırımlar özel sektör yerine devlet tarafindan gerçekleştirilmiş olmaktadır. Devlet borçlanarak elde ettiği söz konusu fonları harcamayıp elinde tutması durumunda emisyon hacminin azalmasına neden olmakta, bu durum ise ekonomide daraltıcı etkilere sebebiyet vermektedir. Öte yandan borçlanma ile sağlanan kaynakların üretken olmayan yerlerde harcanması hasıla artışına bir katkı sağlamamakta ve popülist politika uygulamalarına neden olmaktadır.

Devlet iç borçlanmaya gittiğinde gelecek zaman dilimlerinde bu borçlara ilave olarak faiz ödemek zorundadır. Faiz ödemeleri ise tekrar borçlanmaya gidilmeyip vergi gelirleri ile karşılanırsa, vergi ödeyenlerden devlete borç veren tahvil sahiplerine bir transfer yaşanmaktadır. Tahvil sahipleri genellikle üst gelir gurubuna mensup oldukları için vergi ödeyenlerden bu kişilere bir gelir aktarımı söz konusu olmaktadır. Bu durum da, gelir eşitsizliğini artırıcı bir etki meydana getirmektedir. Literatürde yer alan bir çok ampirik çalışmanın sonuçları da bu hipotezi teyit eder niteliktedir.

Çalışmada Türkiye'de kamu iç borçlanmasının gelir eşitsizliği üzerindeki etkisi 1980-2015 dönemine ait yıllık veriler kullanılarak araştııılmıştır. Bu amaçla Shin vd. (2011) tarafindan geliştirilen NARDL modeli kullanılmıştır. Wald testiyle değişkenler arasında asimetrik ilişki ve sonrasında eşbütünleşme ilişkisinin varlığ 1 belirlendikten sonra, uzun ve kısa dönemli asimetrik katsayılar tahmin edilmiştir. Elde edilen bulgular, uzun dönemde kamu iç borçlanmasında meydana gelecek azalma ya da negatif bir şokun gelir eşitsizliği üzerinde olumsuz bir etkiye sahip olduğunu göstermiştir. Ayrıca pozitif şokun gelir eşitsizliği üzerinde anlamlı herhangi bir etkiye sahip olmadığ 1 görülmüştür. Kısa dönemde de kamu iç borçlanmasındaki bir azalış ya da negatif bir şokun gelir eşitsizliğini istatistiki olarak anlamlı ve negatif etkilediği ancak bir artış ya da pozitif şokun herhangi anlamlı bir etki oluşturmadığı bulgusuna ulaşılmıştır. 
Kısacası kısa ve uzun dönemde kamu iç borçlanmasındaki azalmanın gelir eşitsizliğini azalttığı sonucuna varılmıştır. Bunun yanında kontrol değişkeni olarak modele dahil edilen ekonomik büyüme değişkeninde meydana gelecek artışın ya da azalışın uzun dönemde gelir eşitsizliği üzerinde istatistiki olarak herhangi anlamlı bir etkiye sahip olmadığı gözlemlenmiştir. Bir diğer kontrol değişkeni olan doğrudan yabancı yatırımlardaki bir artışın uzun dönemde gelir eşitsizliğini artırdığı bilgisi elde edilmiştir. Son olarak ticari dişa açıklıktaki hem artış hem de azalışın kısa ve uzun dönemde gelir eşitsizliğini azalttı̆̆ tespit edilmiștir.

Çalışmada yapılan ekonometrik analizden elde edilen sonuçların bir kısmı literatürdeki genel bulguları destekler nitelikte iken, bir kısım sonuçlar da destekler nitelikte değildir. Örneğin, çalışmanın ana araştırma konusunu oluşturan Türkiye'de kamu iç borçlanmasında yaşanan değişimlerin gelir eşitsizliği üzerindeki etkilerini gösteren sonuçlar ampirik literatürü (Kurz ve Rall, 1983; Mankiw, 2000; Salti, 2015; Akram ve Hamid, 2016; Arslan, 2019) destekler niteliktedir. Çalışmada yer alan kontrol değişkenlerinden ekonomik büyümenin gelir eşitsizliği üzerinde herhangi bir etkisinin bulunmadığ 1 yönünde elde edilen sonuç, benzer yönde görüşler ileri süren ve analiz sonuçlarına ulaşan bazı yazarların çalışmalarıyla (Bengoa ve Sanchez-Robles, 2005; Qin vd., 2009) uyumlu iken, aksi yönde (yani ekonomik büyümenin gelir eşitsizliğini etkilediği yönündeki) görüşlere sahip yazarların çalışmalarıyla (Kuznets, 1955; Huang, 2004) çelişmektedir. Bir diğer kontrol değişkeni olan doğrudan yabancı yatırımlarda yaşanan artışların gelir eşitsizliğini artırdığ 1 yönünde ulaşılan sonuç, ana akım (neo klasik) iktisadi teori çerçevesinde öne sürülen fikirlerle (Tsai, 1995; Karabıyık ve Dilber, 2016; Stockhammer, 2017) ters düşmekte iken, heterodoks iktisadi yaklaşım çerçevesinde bağımlılık kuramı üzerinden fikirler ileri süren yazarların görüşleriyle (Ongan, 2004; Mihaylova, 2015; Kaulihowa ve Adjasi, 2017) de örtüşmektedir. Çalışmanın son kontrol değişkeni konumundaki ticari dışa açıklıkta yaşanan artış ya da azalışların gelir eşitsizliğini azalttığ 1 yönünde elde edilen sonuç ise, bu konuda literatürde yer alan teorik çalışmaların hipotezleriyle ve ampirik çalışmaların bulguları ile uyumlu değildir.

Literatürde yer alan temel görüşler ve çalışmada ulaşılan ampirik bulgular doğrultusunda, Türkiye için bazı politika önerilerinde bulunulabilinir. Öncelikle çalışmada elde edilen, Türkiye'de kamu iç borçlanmasında yaşanan azalışların gelir eşitsizliğini azalttığı (gelir dağılımını iyileştirdiği) yönündeki sonuca göre, devletin bütçe açığı ya da başka sebeplerle duyduğu finansman ihtiyacının büyük bir kısmını iç borçlanma ile karşılamak yerine, adil ve eşitlikçi bir vergi sistemi çerçevesinde vergi gelirleriyle karşılamayı tercih etmesi önerilmektedir. Eğer iç borçlanmaya başvurmak kaçınılmaz ise, bu iç borçlanma için dönem sonunda ödenecek faiz tutarlarının, yüksek gelir grubundan alınan bir takım vergi gelirleriyle ödenmesi yoluna da gidilinebilinir. Yani, genellikle yüksek gelir gurubuna mensup kişilerin alabildikleri kamu iç borçlanma senetlerine 
yapılacak faiz ödemelerinin, yine yüksek gelir grubuna dahil kişilerden alınan vergi gelirleriyle karşılanmasıyla kamu iç borçlanmasının gelir eşitsizliğini artırıcı etkisi önlenebilir. Bir diğer öneri ise, iç borçlanma senetlerinden faiz geliri elde edenlere "mümkün olduğu ölçüde" yüksek oranlı vergi uygulanabilinir $\mathrm{ki}$ bu sayede vergilemede adalet ilkesinin tesisine katk1 sağlanmış olunur.

\section{Kaynaklar}

Akdiş, M. (1995), Faiz Politikalarinin Enflasyon Üzerindeki Etkileri ve Türkiye, Ankara: Yimder Yayınları

Akram, N., Hamid, A., (2016), Public Debt, Income Inequality and Macroeconomic Policies: Evidence from South Asian Countries, Pakistan Journal of Social Sciences (PJSS), Vol. 36(1), 99-108.

Arslan, F. P., (2019) Public Debt And Income Inequality In Turkey, Journal of Research in Economics, 3(2), 91-109.

Aspromourgo, T., (2018) Keynes, Public Dept, And The Cmplex of Interest Rates, Journal of the History of Economic Thought, 40(4), 493-512

Banerjee,A., Dolado, J., Mestre, R., (1998), Error-Correction Mechanism Tests for Cointegration in Single Equation Framework, Journal of Time Series Analysis, Vol.19, 267-283

Bayraktar, Y., (2009), İç Borçlanmanın Ekonomik ve Sosyal Etkileri:1980 Sonrası Türkiye Deneyimi, Erciyes Üniversitesi IIIBF Dergisi, 285-313.

Bedir, S., Karabulut, K., (2011), İç Borçların Gelir Dağılımı Üzerine Etkileri, Atatürk Üniversitesi İktisadi ve İdari Bilimler Dergisi, 25(1), 13-30.

Bengoa, M., Sanchez-Robles, B., (2005), Does Equality Reduce Growth? Some Empirical Evidence, Applied Economics Letters, 12(8), 479-483.

Bernheim, B. D., (1989), A Neoclassical Perspective on Budget Deficits, Journal of Economic Perspectives, 3(2), 55-72.

Bilbiie, F., Tommaso, M., Roberto, P., (2013), Public Debt and Redistribution with Borrowing Constraints, The Economic Journal, 123(566), 64-98,

Bilgili, Y., (2010), Karşılaştırmalı İktisat Okulları Ders Notları, İstanbul: İkinci Sayfa Yayınları.

Buchanan, J. M., (1959), Public Principles of Public Debt, The American Economic Review, 49(1), 183-185

Bullock, C. J., (1920), Selected Readings in Public Finance, Boston USA: Ginn Company., $\quad$ https://archive.org/details/selectedreadin00bull/page/n6, Erişim: 02.02.2020

Bulut, C., Canbolat, Y. B., (2003), Türkiye Ekonomisinde Artan Kamu Açıklarının Enflasyon, Faiz Oranı ve Döviz Kuru Üzerindeki Etkileri, Journal of Qafqaz University, V.12, 13-28.

Carcanholo, M. D., (2017), Marx(ism) and Public Debt: Thoughts on the Political Economy of Public Debt, Critique: Journal of Socialist Theory, 45(3), 303-317. 
Çetin, A., (2005), Kamu Borçlarının Makroekonomik Etkileri: Ampirik Bir Analiz, GOP Üniversitesi İktisadi ve İdari Bilimler Dergisi, 19(1), 67-79.

Davenant, C., (1710), An Essay Upon the National Credit of England: Introductory to a Proposal Prepared for Establishing the Public Credit, London, https://archive.org/details/essayuponnationa00daveuoft/page/n4 Erişim: 07.12.2019

Demir, M., Sever, E., (2008), Kamu iç Borçlanmasının Büyüme, Faiz ve Enflasyon Oranı Üzerindeki Etkileri, Elektronik Sosyal Bilimler Dergisi, 7(25), 170-196.

Dyson, K., (2014), States, Debt, and Power: 'Saints' and 'Sinners' in European History and Integrtion, Oxford: Oxford University Press.

Galbraith, J. K., Kum, H., (2005), Estimating the İnequality of Household İncomes: A Statistical Approach to the Creation of A Dense And Consistent Global Data Set, Review of Income and Wealth, 51(1), 115143

Gökçen, A., (2002), Türk Ekonomisinde Borçların Gelişimi, http://readgur.com/doc/80758/i\%CC\%87ndir-202-kb.---prof.-dr.-ahmetmucip-g\%C3\%B6k\%C3\%A7en Erişim Tarihi: 25.12.2019

Gujarati, D. N., (2003) Basic Econometrics, New York: McGraw-Hill.

Jong, Y., Dutt, A. K., (1996), Government Debt, İncome Distribution And Growth, Cambridge Journal of Economics, 20(3), 335-351.

Karabıyık, C., Dilber, İ., (2016), Gelir Eşitsizliği ve Doğrudan Yabancı Sermaye Yatırımları İlişkisi: Panel Veri Analizi, Journal of Yasar University, 11(44), 316-325.

Karaca, O., (2003), Türkiye'de Enflasyon-Büyüme İlişkisi: Zaman Serisi Analizi, Doğuş Üniversitesi Dergisi, 4(2), 247-255.

Kaulihowa, T., Adjasi, C., (2017), FDI and Income Inequality in Africa, Oxford Development Studies, 46(2), 250-265

Kramer, H., Anselmann, C., (2016) Does Government Debt Increase Income Inequality? Historical Roots and Basic Criticisms of the 'Transfer Approach' of Distributional Effects, Preliminary Paper Prepared for 20th Annual FMM Conference, "Towards Pluralism in Macroeconomics?, 20 - 22 October 2016, Berlin.

Kurz, R., Rall, L., (1983), Interpersonal and Intertemporal Distributional Effects of Public Debt, IAW Research Reports Series, No: 38, Tübingen.

Kuznets, S., (1955), Economic Growth and Income Inequality, American Economic Review, No:45, 1- 28.

Loko, B., Mlachila, M., Nallari, R., Kalonji, K., (2003), The İmpact of External İndebtedness on Poverty in Low-Income Countries, IMF Working Paper No. 3/06.

Matsushita, S. T., (1929), The Economic Effects of Public Debts, New York: Columbia

Press, 
Türkiye'de Kamu İ̧̧ Borçlanmasının Gelir Eşitsizliği Üzerindeki Asimetrik Etkisi

https://www.journals.uchicago.edu/doi/abs/10.1086/254321, Erişim: 17.01.2020

Mert, M., Çağlar, A. E., (2019), Eviews ve Gauss Uygulamalı Zaman Serileri Analizi, Ankara: Detay Yayıncilık.

Michl, T. R., (1991), Debt, Deficits, and The Distribution of İncome, Journal of Post Keynesian Economics, 13(3), 351-365

Mihaylova, S., (2015), Foreign Direct Investment and Income Inequality in Central and Eastern Europe, Theoretical and Applied Economics, 22(2) (603), 23-42.

Ongan, T. H., (2004), Gelir Eşitsizliği, Doğrudan Yabancı Sermaye Yatırımları ve Ters U Eğrisi, İktisat Fakültesi Mecmuasl, 54(1), 153-165.

Parasız, M. İ., (2013), Makroekonomi, Bursa: Ezgi Kitabevi.

Pesaran, M. H., Shin, Y., Smith, R. J., (2001), Bounds Testing Approaches to the Analysis of Level Relationships, Journal of Applied Econometrics, V.16, 289-326.

Ricardo, D., (1817). The Principles of Political Economy and Taxation, https://socialsciences.mcmaster.ca/econ/ugcm/3113/ricardo/Principles.pdf, Erişim: 23.12.2019

Qin, D., Cagas, M. A., Ducanes, G., He, X., Liu, R., Liu, S., (2009), Effects of Income Inequality on China's Economic Growth, Journal of Policy Modeling, 31(1), 69-86

Rothbard, M. N., (2006), Economic Thought Before Adam Smith: An Austrian Perspective on the History of Economic Thought, Volume I, H. Edward Elgar Publishing.

Salsman, R. M., (2017), The Political Economy of Public Debt: Three Centuries of Theory and Evidence (New Thinking in Political Economy), UK Northampton: Edward Elgar Publishing.

Salti, N., (2015), Income Inequality and The Composition of Public Debt, Journal of Economic Studies, 42(5), 821-837.

Say, J. B., (1821)-(1971), A Treatise on Political Economy, (Translates from The Fourth Edition of the French, By C.R. Prinsep), New York: M. Kelley Publisher, https://cdn.mises.org/A\%20Treatise\%20on\%20Political\%20Economy 5. pdf Erişim: 27.12.2019

Shin, Y., Yu, B., Greenwood, M., (2014), Modelling Asymmetric Cointegration and Dynamic Multipliers in an ARDL Framework, İçinde: Horrace, W.C., Sickles, R.C. (Eds.), Festschrift in Honor of Peter Schmidt, (s.281-314), New York: Springer Science \& Business Media.

Smith, A., (1776)-(2007), An Inquiry into The Nature and Causes of the Wealth of Nations.

https://www.ibiblio.org/ml/libri/s/SmithA_WealthNations_p.pdf Erişim: 21.12.2019 
Sugözü, H. İ., Erdoğan, S., Ulaşan, E., (2017), The Impacts of Interest Expenditure on Income Distribution and an Application on the Factors Distorting İncome Distribution: An Empirical Analysis For Turkey, Turkish Studies, 12(12), 231-250.

Stockhammer, E., (2017), Determinants of the Wage Share: A Panel Analysis of Advanced And Developing Economies, British Journal of Industrial Relations, 55(1), 3-33.

Tsai, P. L., (1995), Foreign Direct Investment and Income Inequality: Further Evidence, World Development, V.23, 469-483.

Ulusoy, A., Cural, M., (2006), Türkiye'de 1980 Sonrası Dönemde İç Borçların Sürdürülebilirliği, ZKU Sosyal Bilimler Dergisi, 2(4), 1-21.

Zivot, E., Andrews, D. W. K., (1992), Further Evidence on the Great Crash, the Oil-Price Shock, and the Unit-Root Hypothesis, Journal of Business \& Economic Statistics, 10(3), 251-270. 